\title{
Influence of Social Cognitive Cooperation Model with Techniques of Cognitive Restructuring and Engineering Modeling on Self Abasement Students
}

\author{
Pengaruh Model Konseling Kognitif Sosial dengan Teknik Restrukturisasi Kognitif dan \\ Teknik Modeling terhadap Self Abasement Siswa
}

\author{
Ni Putu Nia Diastuti ${ }^{1}$, Dewi Arum W.M.P ${ }^{2}$, I Ketut Dharsana ${ }^{3}$ \\ ${ }^{1}$ Universitas Pendidikan Ganesha \\ e-mail: putrimajiatulhibah58@gmai.com
}

Received July 26, 2017

Revised August 30, 2017

Accepted November 13, 2017

Published Online December 30, 2017

\section{Conflict of Interest}

\section{Disclosures:}

The authors declare that they have no significant competing financial, professional or personal interests that might have influenced the performance or presentation of the work described in this manuscript.

\begin{abstract}
This research is a quasi research ("Quasi Experiment"). The purpose of this research is to know the technique of Cognitive Restructuring in Cognitive Social counseling model influence to Self abasement of class X AP A student, to know Modeling technique in Cognitive Social counseling model influence to Verbal Talent of grade $\mathrm{X}$ AP B students, and to know the difference of technique influence Cognitive Restructuring with Modeling techniques in Social Cognitive counseling model on Self Abasement students. The process of collecting data in this study using observation sheet, interview sheet, diary and Self Abasement questionnaire. Data analysis method used is t-test. From this research the technique of Cognitive Restructuring is more influential than the modeling model of Social Cognitive counseling model in improving Self Abasement of the students of class X AP SMK Negeri 1 Singaraja.
\end{abstract}

Keywords: social cognitive counseling model, techniques cognitive restructuring, modeling techniques self abasement students

\begin{abstract}
Abstrak: Penelitian ini merupakan penelitian semu ("Quasi Eksperiment"). Tujuan dari penelitian ini adalah untuk mengetahui teknik Restrukturisasi Kognitif dalam model konseling Kognitif Sosial berpengaruh terhadap Self abasement siswa kelas X AP A, untuk mengetahui teknik Modeling dalam model konseling Kognitif Sosial berpengaruh terhadap Bakat Verbal siswa kelas X AP B, dan untuk mengetahui perbedaan pengaruh teknik Restrukturisasi Kognitif dengan teknik Modeling dalam model konseling Kognitif Sosial terhadap Self Abasement siswa. Proses pengumpulan data dalam penelitian ini menggunakan lembar observasi, lembar wawancara, buku harian dan kuesioner Self Abasement. Metode analisis data yang digunakan adalah ttest. Dari penelitian ini teknik Restrukturisasi Kognitif lebih berpengaruh dibandingkan dengan teknik Modeling model konseling Kognitif Sosial dalam meningkatkan Self Abasement siswa kelas X AP SMK Negeri 1 Singaraja.
\end{abstract}

Kata Kunci: perbedaan pengaruh model konseling kognitif sosial, teknik restrukturisasi , teknik modeling, self abasement siswa 


\section{Pendahuluan}

Pengamatan peneliti terhadap Self Abasement siswa kelas X AP dan UPW SMK Negeri 1 Singaraja peneliti melihat sebagian siswa menunjukkan Self Abasement, terdapat siswa menunjukkan merasa bersalah bila melakukan kesalahan, menerima salah bila melakukan sesuatu yang tidak benar, dan lebih merasakan kesengsaraan dan kesediahan ketika nmelakukan kesalahan.

Menurut Dharsana (2010:2) self abasement adalah kebutuhan untuk bisa mengalah meliputi merasa bersalah bila melakukan kesalahan, menerima salah bila melakukan sesuatu yang tidak benar, lebih mendapatkan kesengsaraan dan kesedihan dari melakukan kesalahan. Berdasarkan definisi tersebut maka abasement dalam hal ini mengandung 3 aspek, yaitu : (1) merasa bersalah bila melakukan kesalahan, (2) menerima salah bila melakukan sesuatu yang tidak benar, (3) Lebih mendapatkan kesengsaraan dan kesedihan dari melakukan kesalahan (Bere, 2011; Ć \& Duyvendak, 2016; Caldas, 2015; Jiansheng, 2017; Miniati, 2008; Nadelhoffer, Wright, Echols, Perini, \& Venezia, 2016) .

Bimbingan adalah proses pemberian bantuan oleh orang yang ahli kepada seseorang atau beberapa orang individu, baik anak-anak, remaja, maupun dewasa. (Dharsana, 2010:261). Hasil observasi yang dilakukan terhadap siswa di kelas X AP A, X AP B, X UPW C di SMK Negeri 1 Singaraja, diketahui bahwa terdapat sebagian siswa yang mengalami gejala-gejala Self Abasement rendah seperti beberapa siswa yang tidak merasa bersalah bila melakukan kesalahan, tidak menerima salah bila melakukan sesuatu yang tidak benar, dan tidak merasakan kesengsaraan dan kesediahan ketika nmelakukan kesalahan.

Penulis menggunakan teori konseling Kognitif Sosial yang dikembangkan oleh Albert Bandura. Berdasarkan hal tersebut, maka dalam penelitian ini model konseling yang digunakan adalah model konseling Kognitif Sosial.

Teori ini mengakui baik adanya kontribusi sosial terhadap cara manusia berpikir dan bertindak, maupun pentingnya proses kognitif terhadap motivasi, emosi dan tindakan. Teori ini mampu menjelaskan cara pembentukan perilaku manusia yang tidak dapat dijelaskan secara memadai oleh perspektif aliran Skinnerian tentang bagaimana prinsip-prinsip reinforcement beroperasi (Ainslie, 1975; Azzi, Baqueira, \& Tourinho, 2016; Bandura, 1991; Espejo, Gorlick, \& Castriotta, 2016; Freud, Mahler, Strauss, \& Sch, 2017; Garriott, Raque-bogdan, Zoma, Mackie-hernandez, \& Lavin, 2016; Hill, 1987; Lent, Brown, \& Hackett, 2000; Mischel, 1973; Rapee \& Heimberg, 1997; 江光荣 2008)

Gejala Self abasement diatas, akan dapat ditingkatkan manakala disentuh dan di"treatmen" dengan cara atau teknik yang selaras dengan teori konseling. Adapun beberapa teknik dalam pendekatan Kognitif Sosial yaitu: 1) teknik penjadwalan kegiatan, 2) teknik kognitif restructuring (cognitive restructuring), 3) teknik biblioterapi, 4) penghentian pikiran, 5) percontohan (modeling), 6) teknik reframing dan relabeling dari beberapa teknik yang terdapat pada konseling Kognitif Sosial, dalam penelitian ini peneliti memilih teknik modeling dan cognitive restructuring.

Menurut Bandura (dalam terjemahan E. Koswara, 1988:221) "teknik modeling merupakan observasi permodelan, mengobservasi seseorang lainnya sehingga seseorang tersebut membentuk ide dan tingkah laku, kemudian dijelaskan sebagai panduan untuk bertindak". Bandura juga menegaskan bahwa modeling merupakan konsekuensi perilaku meniru orang lain dari pengalaman baik pengalaman langsung maupun tidak langsung, sehingga reaksi-reaksi emosional dan rasa takut seseorang dapat dihapuskan (Devi, Das, Das, \& Khandelwal, 2017; Faasse, Perera, Loveys, Grey, \& Petrie, 2017; Guido et al., 2017; Moisen \& Frescino, 2002; Ricardo et al., 2016; Staay, 2006; Taylor, Russ-eft, \& Chan, 2005).

Restrukturisasi kognitif adalah proses belajar untuk menyangkal distorsi kognitif atau fundamental "kesalahan berpikir," dengan tujuan menggantikan pikiran seseorang yang tidak rasional, keyakinan kontra-faktual yang akurat dan dominan (Astuti, Sumarwati, \& Seyiono, 2010; Bryant et al., 2003; Foa et al., 2005; Hawley et al., 2017; Jiansheng, 2017; Miniati, 2008; Neimeyer, Kazantzis, Kassler, Baker, \& Fletcher, 2008) .

Tujuan penelitian ini yaitu Untuk mengetahui pengaruh teknik Restrukturisasi Kognitif dalam model konseling Kognitif Sosial terhadap peningkatan Self abasement siswa kelas X AP A, Untuk mengetahui pengaruh teknik Modeling dalam model konseling Kognitif Sosial terhadap peningkatan Bakat Verbal siswa kelas X AP B, Untuk mengetahui perbedaan pengaruh teknik Restrukturisasi Kognitif dengan teknik Modeling dalam model konseling Kognitif Sosial terhadap peningkatan Self Abasement siswa. 


\section{Metode}

Desain Eksperimen merupakan semua proses yang diperlukan dalam perencanaan dan pelaksanaan penelitian (Umar,2004:30). Dalam penelitian ini, desain penelitian yang digunakan adalah "Nonrandomized Control Group Pretes-Postest Desain". Menurut Sukardi (2012:186), "Nonrandomized Control Group Pretes-Postest Desain" merupakan model eksperimen semu ("quasi ekperiment"). Dantes (2012:97) menyatakan bahwa, dalam penelitian kuasi sering digunakan "intact group", seperti kelas sehingga randomisasi tidak dapat dilakukan Menurut Corey (2013:134),

Berdasarkan hal tersebut diatas, maka teknik pengambilan sampel yang digunakan adalah teknik "Simple Random Sampling" dengan cara undian. Sehingga, dapat diketahui sampel dalam penelitian ini adalah siswa kelas X AP A, X AP B, X UPW C.

Pengamatan (Observasi) adalah teknik pengumpulan data yang dilakukan dengan cara mengamati dan mencatat gejala-gejala yang akan diselidiki (Narbuko, dkk 2013:70). Observasi dilakukan dengan tujuan 1) memperoleh informasi tentang kelakuan manusia seperti terjadi dalam kenyataan, 2) memperoleh gambaran yang lebih jelas tentang kehidupan sosial, yang sukar diperoleh dengan metode lain, 3) observasi dilakukan bila belum banyak keterangan dimiliki oleh peneliti tentang masalah yang diselidiki (Nasution, 2008:106). Menurut Narbuko, dkk (2013:73) macam-macam alat observasi yaitu: 1) "Anecdotal record", 2) Catatan Berkala, 3) "Check list", 4) "Rating Scale", 5) "Mechanical Devices". Teknik pengumpulan data dalam penelitian ini adalah 1) teknik pengamatan, 2) teknik wawancara, 3) kuisioner, 4) Dokumen dan artefak,

Untuk memperoleh data tentang Self abasement digunakan beberapa instrument penelitian yaitu 1) Lembar Observasi, 2) Lembar Wawancara, 3) Buku Harian, dan 4) Kuesioner. Berikut merupakan penjelasan mengenai instrument yang akan digunakan dalam penelitian ini. Dalam pelaksanaan observasi, aspek-aspek Self abasement yang diamati mengacu pada indikator-indikator dari ketiga aspek dalam Self abasement (1) merasa bersalah bila melakukan kesalahan, (2) menerima salah bila melakukan sesuatu yang tidak benar, (3) Lebih mendapatkan kesengsaraan dan kesedihan dari melakukan kesalahan.

\section{Hasil dan Pembahasan}

Variabel yang dikaji dalam penelitian ini adalah Self Abasement siswa di kelas X AP A, X AP B, dan X UPW C SMK Negeri 1 Singaraja. Dari data awal yang diperoleh, sebagian siswa menunjukkan Self Abasement yang rendah seperti menunjukan tidak merasa bersalah bila melakukan kesalahan, tidak menerima salah bila melakukan sesuatu yang tidak benar, dan tidak merasakan kesengsaraan dan kesediahan ketika nmelakukan kesalahan.

Terdapat siswa yang menunjukkan gejala-gejala Self Abasement yang bersifat positif (+) maupun negatif (-). Secara kuantitatif, jumlah siswa yang menunjukkan gejala-gejala Self Abasement yang bersifat positif (+) sebanyak 100 orang dan yang menunjukkan gejala-gejala Self Abasement yang bersifat negatif (-) sebanyak 27 orang. Secara persentase, 58\% siswa menunjukkan gejala-gejala Self Abasement bersifat positif (+) dan $42 \%$ siswa menunjukkan gejala-gejala Self Abasement yang bersifat negatif (-). Sehingga, dari data awal ini maka dapat diketahui bahwa kelompok siswa yaitu X AP A, X AP B, X UPW C, lebih banyak menunjukkan gejala - gejla Self Abasement yang bersifat positif $(+)$ daripada yang bersifat negatif $(-)$.

Berdasarkan data hasil observasi yang dilaksanakan dalam setiap layanan model konseling Kognitif Sosial teknik modeling, dapat diketahui bahwa terjadi penurunan gejala-gejala Self Abasement siswa kelompok eksperimen I yang bersifat (-) pada setiap layanan yang diberikan. Dalam bimbingan klasikal, terdapat 8 orang siswa yang menunjukkan gejala-gejala Self Abasement negatif (-) yang selanjutnya direkomendasikan mengikuti bimbingan kelompok. Kemudian dalam bimbingan kelompok, 5 orang siswa menunjukkan gejala-gejala Self Abasement negatif (-) yang selanjutnya direkomendasikan mengikuti konseling kelompok. Selanjutnya dalam konseling kelompok, 1 orang siswa menunjukkan gejala-gejala Self Abasement negatif (-) yang selanjutnya mengikuti konseling individu. Setelah pelaksanaan layanan model konseling Kognitif Sosial teknik modeling, seluruh siswa kelompok eksperimen I sudah mampu menunjukkan gejala-gejala Self Abasement positif (+) Sehingga, pemberian "treatment" pada kelompok 
eksperimen I dengan model konseling Kognitif Sosial teknik Restrukturisasi kognitif memberikan pengaruh yang positif terhadap Self Abasement siswa.

Berdasarkan data hasil observasi yang dilaksanakan dalam setiap layanan model konseling Kognitif Sosial teknik Modeling, dapat diketahui bahwa terjadi penurunan gejala-gejala Self Abasement siswa kelompok eksperimen II yang bersifat (-). Dalam bimbingan klasikal, terdapat 8 orang siswa yang menunjukkan gejala-gejala Self Abasement negatif (-) yang selanjutnya direkomendasikan mengikuti bimbingan kelompok. Kemudian dalam bimbingan kelompok, ditemukan 4 orang siswa menunjukkan gejala-gejala Self Abasement negatif (-) yang selanjutnya direkomendasikan mengikuti konseling kelompok. Kemudian dalam konseling kelompok, ditemukan 1 orang siswa menunjukkan gejala-gejala Self Abasement yang negatif (-) yang selanjutnya direkomendasikan mengikuti konseling individu. Setelah pelaksanaan layanan model konseling Kognitif Sosial teknik Modeling, siswa kelompok eksperimen II sudah mampu menunjukkan gejala-gejala Self Abasement yang positif (+). Sehingga, pemberian "treatment" pada kelompok eksperimen II dengan model konseling Kognitif Sosial teknik Modeling memberikan pengaruh yang positif terhadap Self Abasement siswa.

\section{Skor Buku Harian Kelompok Eksperimen I}

Setelah masing-masing individu siswa kelompok eksperimen I mengisi buku harian, selanjutnya skor buku harian masing-masing individu siswa kelompok eksperimen I di masukkan kedalam tabel skor buku harian secara kelas. Berikut merupakan tabel skor buku harian siswa kelompok eksperimen I secara kelas

\section{Tabel 4.9 Skor Buku Harian Siswa Kelompok Eksperimen I kelas X AP A SMKN 1 Singaraja}

\begin{tabular}{|c|c|c|c|c|c|c|}
\hline & & & |ARI & & & \\
\hline 1 & 2 & 3 & 4 & 5 & 6 & 7 \\
\hline 36.2 & 39.4 & 41 & 43.6 & 46 & 48.4 & 51 \\
\hline
\end{tabular}

Selanjutnya skor buku harian siswa kelompok eksperimen I dimasukkan ke dalam grafik harian sebagai berikut

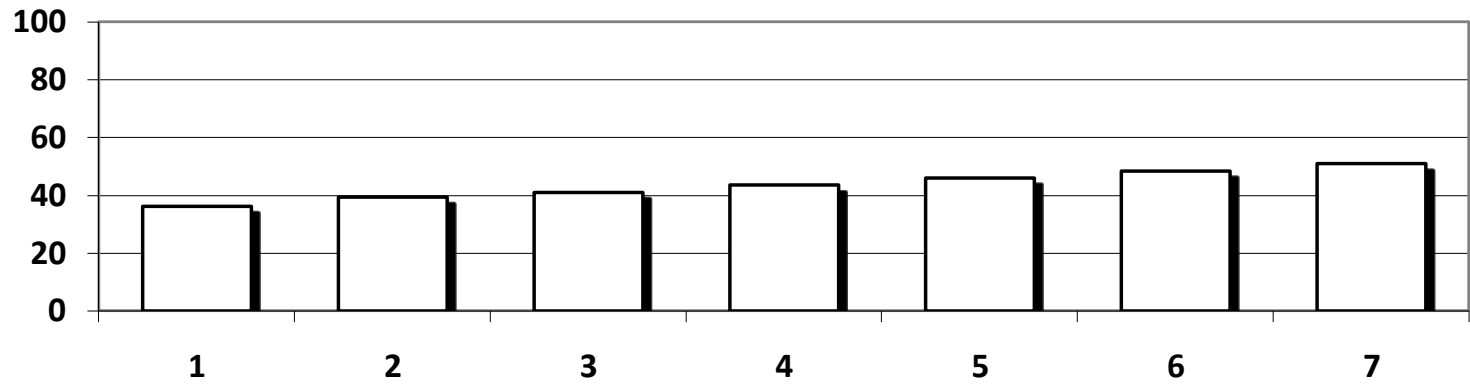

Gambar 4.3 Grafik Buku Harian Siswa Kelompok Eksperimen I

Setelah skor buku harian masing-masing individu siswa kelompok eksperimen I dimasukkan ke dalam grafik harian, selanjutnya skor buku harian mingguan masing-masing individu siswa kelompok eksperimen I ditabulasi dari skor hariannya. Berikut tabulasi skor buku harian mingguan siswa eksperimen I secara kelas. 
Tabel 4.10 Skor Buku Harian Mingguan Siswa Kelompok Eksperimen I kelas X AP A SMKN N 1 Singaraja

\begin{tabular}{cccc}
\hline \multicolumn{5}{c}{ MINGGU } \\
\hline $\mathbf{1}$ & $\mathbf{2}$ & $\mathbf{3}$ & $\mathbf{4}$ \\
$\mathbf{1 2 . 6}$ & 30.5 & 50.4 & 81.06 \\
& & & \\
\hline
\end{tabular}

Selanjutnya tabulasi rata-rata skor buku harian mingguan siswa kelompok eksperimen I tersebut dimasukkan ke dalam grafik mingguan :

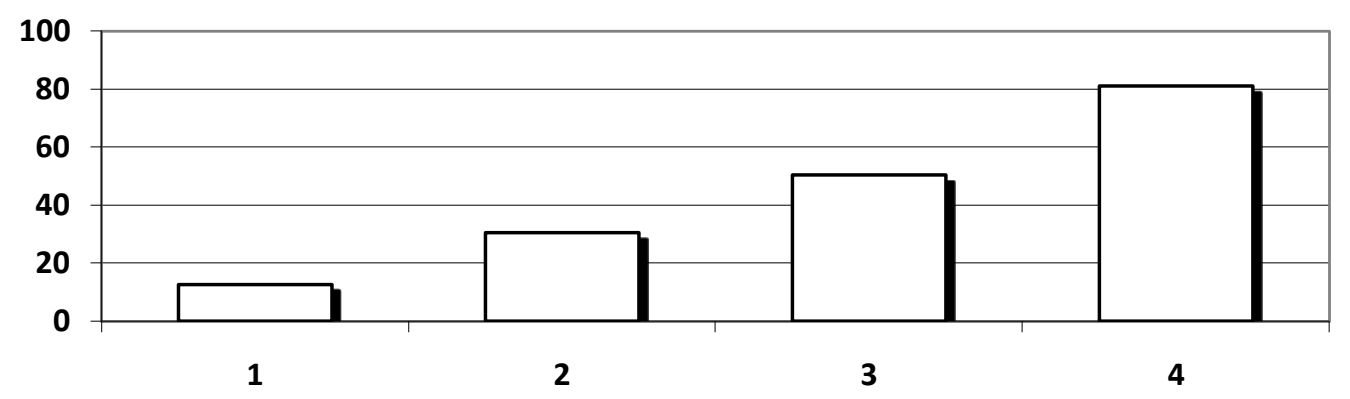

\section{Gambar 4.4 Grafik Buku Harian Mingguan Kelompok Eksperimen I}

Berdasarkan data hasil buku harian kelompok eksperimen I, maka dapat diketahui bahwa terjadi penigkatan skor buku harian siswa kelompok eksperimen I dalam setiap layanan model konseling Kognitif Sosial teknik restrukturisasi kogntif yang diberikan. Sehingga, dari buku harian dan mingguan ini dapat diketahui bahwa pelaksanaan model konseling Kognitif Sosial teknik modeling berkontribusi positif terhadap Self Abasement siswa kelompok eksperimen I.

\section{Skor Buku Harian Kelompok Eksperimen II}

Setelah masing-masing individu siswa dalam kelompok eksperimen II mengisi buku harian, skor buku harian masing-masing individu siswa kelompok eksperimen II di masukkan kedalam tabel skor buku harian secara kelas. Berikut merupakan tabel skor buku harian siswa secara kelas

Tabel 4.11 Skor Buku Harian Siswa Kelompok Eksperimen II

\begin{tabular}{cccccccc}
\hline \multicolumn{1}{c}{ HARI } \\
\hline $\mathbf{1}$ & $\mathbf{2}$ & $\mathbf{3}$ & $\mathbf{4}$ & $\mathbf{5}$ & $\mathbf{6}$ & $\mathbf{7}$ \\
$\mathbf{3 5 . 9}$ & 38 & 41.1 & 43.3 & 45.9 & 47.9 & 50.4 & \\
\hline
\end{tabular}

Setelah seluruh tabel skor buku harian terdata, selanjutnya jumlah skor buku harian dirata-ratakan untuk mendapatkan data buku harian secara kelas yang kemudian dimasukkan ke dalam grafik harian. Berikut merupakan grafik harian kelompok eksperimen II: 


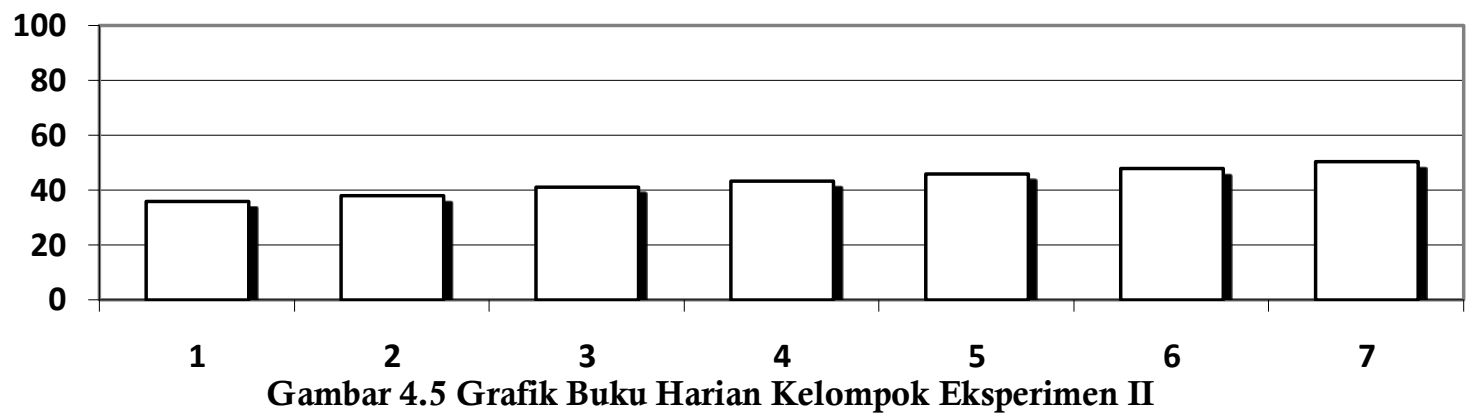

Setelah skor buku harian siswa kelompok eksperimen II dimasukkan ke dalam grafik harian, selanjutnya skor buku harian mingguan siswa kelompok eksperimen II ditabulasi dari skor hariannya. Berikut tabulasi skor buku harian mingguan siswa kelompok eksperimen II.

Tabel 4.10 Skor Buku Harian Mingguan Siswa Kelompok Eksperimen II kelas X AP B SMAN 1 Singaraja

\begin{tabular}{cccc}
\hline \multicolumn{5}{c}{ MINGGU } & $\mathbf{4}$ \\
\hline $\mathbf{1}$ & $\mathbf{2}$ & $\mathbf{3}$ & 79.3 \\
\hline
\end{tabular}

Selanjutnya tabulasi rata-rata skor buku harian mingguan siswa kelompok eksperimen II tersebut dimasukkan ke dalam grafik mingguan sebagai berikut:

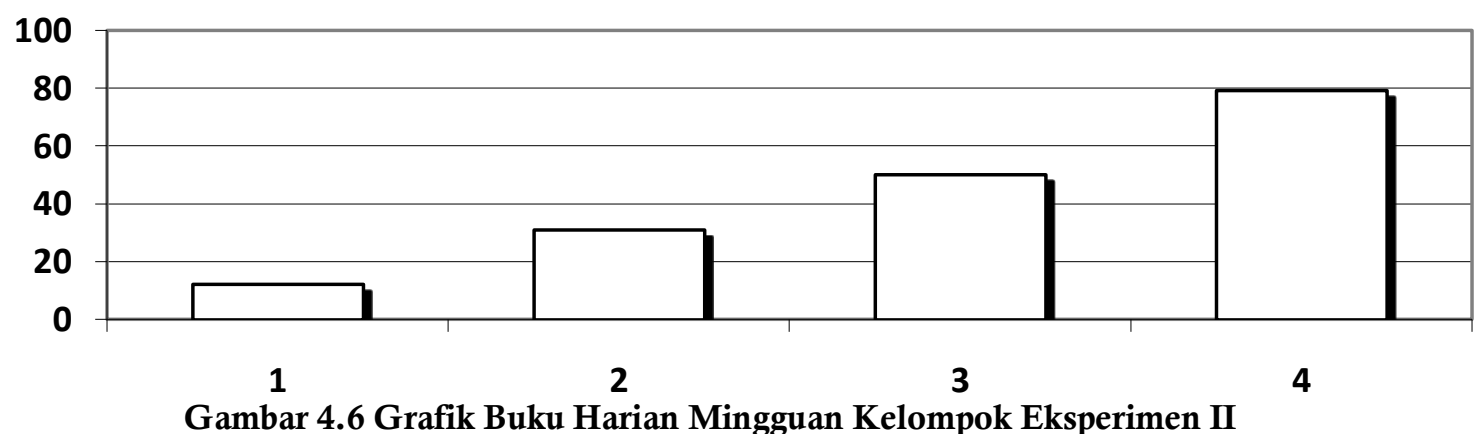

Berdasarkan data hasil buku harian siswa, maka dapat diketahui bahwa terjadi penigkatan skor buku harian siswa dalam setiap layanan yang diberikan. Sehingga, dari buku harian, mingguan dan bulanan ini dapat diketahui bahwa pelaksanaan model konseling Kognitif Sosial teknik modeling berkontribusi positif terhadap Self Abasement siswa kelompok eksperimen II. Hal ini terlihat dari siswa yang tertib terhadap sarana dan prasarana pembelajaran, tertib dalam menyampaikan ide-ide dalam pembelajaran, mencatat dan mengatur tugas dengan rapi, membuat rencana sebelum memulai suatu tugas yang sukar, dan mengelola diri dengan baik di sekolah.

Berdasarkan hasil pelaksanaan "Pre-Test" pada kelompok eksperimen I menggunakan kuesioner Self Abasement, dapat diketahui bahwa 3 orang siswa berada dalam kategori sangat tinggi, 21 orang siswa berada dalam kategori tinggi, 17 orang siswa berada dalam kategori sedang, dan 1 orang siswa berada dalam kategori rendah.

Berdasarkan hasil pelaksanaan "Post-Test" pada kelompok eksperimen I menggunakan kuesioner Self Abasement, dapat diketahui bahwa 13 orang siswa berada dalam kategori sangat tinggi, 27 orang siswa berada dalam kategori tinggi, dan 2 orang siswa berada dalam kategori sedang.

Setelah diketahui skor pre-test dan post-test pada kelompok eksperimen I dan kelompok kontrol, selanjutnya dilakukan uji efektivitas antara eksperimen I dengan kontrol. Ternyata thitung $=2,94>2,01$, 
sehingga Ho ditolak dan Ha diterima. Maka dapat disimpulkan bahwa teknik restrukturisasi kognitif dalam model konseling Kognitif Sosial berpengaruh terhadap Self abasement siswa X AP A antara eksperimen I dan kontrol adalah $\left(\overline{X_{1}}=14,63>\overline{X_{2}}=11,30\right)$.

Berdasarkan hasil pelaksanaan "Pre-Test" pada kelompok eksperimen II menggunakan kuesioner Self abasement, dapat diketahui bahwa 4 orang siswa berada dalam kategori sangat tinggi, 31 orang berada dalam kategori tinggi, 6 orang siswa berada dalam kategori sedang, dan 2 orang siswa berada dalam kategori rendah..

Berdasarkan hasil pelaksanaan "Post-Test" pada kelompok eksperimen II menggunakan kuesioner Self abasement, dapat diketahui bahwa 7 orang siswa berada dalam kategori sangat tinggi, 28 orang siswa berada dalam kategori tinggi, dan 8 orang siswa berada dalam kategori sedang.

Setelah diketahui skor pre-test dan post-test pada kelompok eksperimen II dan kelompok kontrol, selanjutnya dilakukan uji efektivitas antara eksperimen II dengan kontrol. Ternyata thitung $=4,55>2,01$, sehingga HO ditolak dan Ha diterima. Maka dapat disimpulkan bahwa teknik modeling dalam model konseling Kognitif Sosial berpengaruh terhadap Self abasement siswa X AP B antara eksperimen II dan kontrol adalah $\left(\overline{X_{1}}=11.30>\overline{X_{2}}=7,47\right)$.

Hasil analisis data kuesioner Self abasement kelompok eksperimen I dan eksperimen II, harga Fhitung $=12,57>$ dari Ftabel = 1,69 ); ini berarti H0 ditolak dan Ha diterima; jadi varians tidak homogen. Selanjutnya, dilanjutkan dengan analisis menggunakan t-test dengan hasil $\mathrm{t}$ hitung $=2,94>2.01$, sehingga H0 diterima dan Ha ditolak. Maka dapat disimpulkan bahwa terdapat perbedaan pengaruh Self abasement antara siswa yang mendapat "treatment" teknik restrukturisasi kognitif dengan siswa yang mendapat "treatment" teknik Modeling dalam model konseling Kognitif Sosial

Pembahasan hasil penelitian yang dipaparkan pada bagian ini adalah hasil-hasil analisis deskriptif dan analisis statistik yang meliputi:

\section{Teknik Restrukturisasi Kognitif dalam Model Konseling Kognitif Sosial Efektif terhadap Self Abasement Siswa Kelas X AP A}

Teknik Restrukturisasi Kognitif merupakan suatu strategi yang digunakan untuk melatih konseli secara mental bentuk - bentuk perilaku baru yang lebih efektif dan kemudian menciptakan suatu model kognitif bagi dirinya sendiri untuk membentuk perilaku tersebut dengan berhasil. Restrukturisasi kognitif adalah proses belajar untuk menyangkal distorsi kognitif atau fundamental "kesalahan berpikir," dengan tujuan menggantikan pikiran seseorang yang tidak rasional, keyakinan kontra-faktual yang akurat dan dominan. Dalam hal ini, teknik Cognitive Restructuring diaplikasikan dalam model konseling Kognitif Sosial berupa layanan bimbingan klasikal, bimbingan kelompok, konseling kelompok, dan konseling individu pada siswa kelas X AP A 1 SMK Negeri 1 Singaraja sebagai kelompok eksperimen I.

Hasil observasi yang dilakukan dalam setiap pertemuan, menunjukkan bahwa terjadi penurunan jumlah siswa yang mengalami Self abasement yang rendah. Hasil observasi dalam bimbingan klasikal menemukan 8 orang siswa menunjukkan gejala Self abasement negatif yang selanjutnya direkomendasikan mengikuti bimbingan kelompok. Kemudian hasil observasi dalam bimbingan kelompok menemukan 5 orang siswa menunjukkan gejala Self abasement negatif yang selanjutnya mengikuti konseling kelompok. Kemudian hasil observasi dalam konseling kelompok menemukan 1 orang siswa menunjukkan gejala Self abasement yang bersifat negatif yang selanjutnya direkomendasikan mengikuti konseling individu. Setelah konseling individu dilaksanakan, siswa sudah mampu menunjukkan gejala yang bersifat positif. Dari data hasil observasi tersebut, dapat diketahui bahwa setelah diberikan "treatment" model konseling Kognitif Sosial teknik restrukturisasi kognitif, terjadi penurunan Self Abasement siswa yang bersifat negatif. Sehingga, jumlah siswa yang mengalami gejala-gejala Self Abasement yang rendah dapat berkurang.

Temuan empiris pada penelitian ini menyatakan bahwa teknik restrukturisasi kognitif dalam model konseling Kognitif Sosial efektif terhadap bakat verbal siswa kelas X AP A. Hasil uji F diketahui bahwa kedua varians tidak homeogen dimana Fhitung $>$ Ftabel $(12,57>1,69)$. Kemudian dilakukan uji $t$ didapatkan hasil bahwa Harga thitung diperoleh 2,94 dan Harga ttabel sebesar 2,01. Jika dibandingkan Harga thitung dengan Harga ttabel didapatkan bahwa 2,94 $>2,01$ artinya Harga thitung $>$ Harga ttabel dengan db 41 dan 41 dan taraf siginifikansi 5\% $(\alpha=0,05)$. Ini berarti bahwa Ho ditolak dan Ha diterima. 
Untuk itu, hipotesis pertama yaitu teknik restruturisasi kognitif dalam model konseling Kognitif Sosial berpengaruh terhadap peningkatan Self Abasement siswa kelas X AP A SMK Negeri 1 Singaraja diterima. Sehingga dapat diketahui bahwa teknik Restrukturisasi Kognitif dalam model konseling Kognitif Sosial berpengaruh terhadap peningkatan Self Abasement siswa kelas X AP A SMK Negeri 1 Singaraja.

\section{Teknik Modeling dalam Model Konseling Kognitif Sosial Efektif terhadap Self Abasement Siswa Kelas X AP B}

Teknik modeling merupakan suatu proses belajar yang dilakukan dengan cara mengamati model. Teknik modeling dapat dilakukan secara langsung, simbolik dan tertutup. Hal serupa dijelaskan oleh Bandura, yang dimaksud teknik modeling adalah suatu teknik dalam konseling yang menggunakan proses belajar melalui pengamatan terhadap model dan perubahan perilaku yang terjadi karena peniruan. Dalam hal ini, teknik modeling diaplikasikan dalam model konseling Kognitif Sosial berupa layanan bimbingan klasikal, bimbingan kelompok, konseling kelompok, dan konseling individu pada siswa kelas X AP B SMK Negeri 1 Singaraja sebagai kelompok eksperimen II.

Hasil observasi yang dilakukan dalam setiap pertemuan, menunjukkan bahwa terjadi penurunan jumlah siswa yang mengalami Self abasement yang rendah. Hasil observasi dalam bimbingan klasikal menemukan 8 orang siswa menunjukkan gejala Self abasement negatif yang selanjutnya direkomendasikan mengikuti bimbingan kelompok. Kemudian hasil observasi dalam bimbingan kelompok menemukan 5 orang siswa menunjukkan gejala Self abasement negatif yang selanjutnya mengikuti konseling kelompok. Kemudian hasil observasi dalam konseling kelompok menemukan 1 orang siswa menunjukkan gejala Self abasement yang bersifat negatif yang selanjutnya direkomendasikan mengikuti konseling individu. Setelah konseling individu dilaksanakan, siswa sudah mampu menunjukkan gejala Self abasement yang bersifat positif. Dari data hasil observasi tersebut, dapat diketahui bahwa setelah diberikan "treatment" model konseling Kognitif Sosial teknik Restrukturisasi Kognitif , terjadi penurunan Self abasement siswa yang bersifat negatif. Sehingga, jumlah siswa yang mengalami gejala-gejala Self abasement yang rendah dapat berkurang.

Temuan empiris pada penelitian ini menyatakan bahwa teknik restrukturisasi kognitif dalam model konseling Kognitif Sosial efektif terhadap Self abasement siswa kelas X AP B. Hasil uji F diketahui bahwa kedua varians tidak homeogen dimana Fhitung $>$ Ftabel $(1,09>1,69)$. Kemudian dilakukan uji t didapatkan hasil bahwa Harga thitung diperoleh 4,55 dan Harga ttabel sebesar 2,01. Jika dibandingkan Harga thitung dengan Harga ttabel didapatkan bahwa 4,55> 2,01 artinya Harga thitung > Harga ttabel dengan db 41 dan 41 dan taraf siginifikansi 5\% $(\alpha=0,05)$. Ini berarti bahwa Ho ditolak dan Ha diterima. Untuk itu, hipotesis pertama yaitu teknik restrukturisasi kognitif dalam model konseling Kognitif Sosial berpengaruh terhadap peningkatan Self abasement siswa kelas X AP A SMK Negeri 1 Singaraja diterima. Sehingga dapat diketahui bahwa teknik Restrukutrissasi Kognitif dalam model konseling Kognitif Sosial berpengaruh terhadap peningkatan Self abasement siswa kelas X AP A SMK Negeri 1 Singaraja.

Hasil observasi yang dilakukan dalam setiap pelaksanaan layanan, menunjukkan bahwa terjadi penurunan jumlah siswa yang mengalami Self Abasement yang rendah. Hasil observasi dalam bimbingan klasikal menemukan 8 orang siswa yang menunjukkan gejala Self Abasement negatif yang selanjutnya direkomendasikan mengikuti bimbingan kelompok. Kemudian hasil observasi dalam bimbingan kelompok menemukan 4 orang siswa menunjukkan gejala Self Abasement negatif yang selanjutnya direkomendasikan mengikuti konseling kelompok. Selanjutnya hasil observasi dalam konseling kelompok menemukan 1 orang siswa menunjukkan gejala Self Abasement negatif yang selanjutnya direkomendasikan mengikuti konseling individu. Setelah dilakukan konseling individual, siswa sudah mampu menunjukkan gejala-gejala Self Abasement yang bersifat positif. Dari data hasil observasi tersebut, dapat diketahui bahwa setelah diberikan "treatment" model konseling Kognitif Sosial teknik modeling, terjadi penurunan Self Abasement siswa yang bersifat negatif. Sehingga, jumlah siswa yang mengalami gejala-gejala Self Abasement yang rendah dapat berkurang.

Temuan empiris pada penelitian ini menyatakan bahwa teknik Cognitive Restructuring dalam model konseling Kognitif Sosial efektif terhadap bakat verbal siswa kelas X UPW B. Hasil uji F diketahui bahwa kedua varians tidak homeogen dimana Fhitung $>$ Ftabel $(1,71>1,69)$. Kemudian dilakukan uji $t$ didapatkan hasil bahwa Harga thitung diperoleh 3,16 dan Harga ttabel sebesar 2,01. Jika dibandingkan Harga thitung dengan Harga ttabel didapatkan bahwa 4,55 > 2,01 artinya Harga thitung $>$ Harga ttabel 
dengan db 42 dan 41 dan taraf siginifikansi 5\% $(\alpha=0,05)$. Ini berarti bahwa Ho ditolak dan Ha diterima. Untuk itu, hipotesis kedua yaitu teknik Modeling model konseling Kognitif Sosial berpengaruh terhadap peningkatan Self Abasement siswa kelas X AP B SMK Negeri 1 Singaraja diterima. Sehingga dapat diketahui bahwa teknik Restrukturisasi Kognitif dalam model konseling Kognitif Sosial berpengaruh terhadap peningkatan Self Abasement siswa kelas X AP B SMK Negeri 1 Singaraja.

\section{Perbedaan Efektivitas Teknik Restrukturisasi Kognitif dengan Teknik Modeling Konseling Kognitif Sosial terhadap Self Abasement Siswa}

Untuk memberikan "treatment" terhadap Self Abasement siswa, teknik yang digunakan adalah teknik restruturisasi kognitif dan teknik modeling.

Teknik restruturisasi kognitif diaplikasikan dalam model konseling Kognitif Sosial berupa layanan bimbingan klasikal, bimbingan kelompok, konseling kelompok, dan konseling individu pada siswa kelas $\mathrm{X}$ AP A SMK Negeri 1 Singaraja sebagai kelompok eksperimen I.

Dalam hal ini, teknik Modeling diaplikasikan dalam model konseling Kognitif Sosial berupa layanan bimbingan klasikal, bimbingan kelompok, konseling kelompok, dan konseling individu pada siswa kelas X AP B SMK Negeri 1 Singaraja sebagai kelompok eksperimen II.

Teknik restrukturisasi kognitif dengan teknik modeling telah terbukti efektif dalam meminimalisir Self abasement siswa pada kelompok eksperimen. Dari hasil observasi dan pengujian data kuesioner Self abasement pada "pre-test" dan "post-test", terdapat perbedaan yang signifikan. Sehingga, gejala-gejala Self abasement siswa yang bersifat negatif mengalami penurunan.

Temuan empiris pada penelitian ini, menyatakan bahwa terdapat perbedaan efektivitas antara teknik restrukturisasi kognitif dengan teknik Modeling model konseling Kognitif Sosial terhadap bakat verbal siswa. Hasil uji $\mathrm{F}$ menyatakan bahwa kedua varian tidak homogen dimana Fhitung $>$ Ftabel yaitu 12,57 > 1,69 (db 41 dan 42 dengan $\alpha=0,05$ ). Dari hasil uji t bahwa Harga thitung diperoleh 2,94 dan Harga ttabel sebesar 2,01. Jika dibandingkan Harga thitung dengan Harga ttabel didapatkan bahwa 1,09 > 2,01 artinya Harga thitung > Harga ttabel dimana db 41 dan 42 dengan taraf siginifikansi $5 \%(\alpha=0,05)$. Ini membuktikan bahwa, terdapat perbedaan antara teknik restrukturisasi kognitif dengan teknik Modeling model konseling Kognitif Sosial terhadap Self Abasement siswa. Dari hasil rerata hitung, didapatkan $X_{1}$ $=14,63>\overline{X_{2}}=11,30$, artinya nilai rerata hitung teknik restrukturisasi kognitif lebih besar daripada teknik Modeling. Ini berarti Ho ditolak dan Ha diterima. Untuk itu hipotesis ketiga yaitu terdapat perbedaan pengaruh model konseling Kognitif Sosial teknik restrukturisasi kognitif dengan teknik Modeling terhadap peningkatan self abasement siswa SMK Negeri 1 Singaraja diterima. Sehingga dapat diketahui bahwa terdapat perbedaan pengaruh teknik restrukturisasi kognitif dengan teknik Modeling model konseling Kognitif Sosial terhadap Self abasement siswa SMK Negeri 1 Singaraja dimana teknik modeling lebih efektif terhadap Self abasement siswa.

\section{Kesimpulan}

Berdasarkan hasil penelitian dapat diambil kesimpulan yaitu sebagai berikut:

1. Temuan empiris pada penelitian ini, menyatakan bahwa terdapat perbedaan efektivitas antara teknik restrukturisasi kognitif dengan teknik Modeling model konseling Kognitif Sosial terhadap bakat verbal siswa.

2. Terdapat perbedaan antara teknik restrukturisasi kognitif dengan teknik Modeling model konseling Kognitif Sosial terhadap Self Abasement siswa.

3. Terdapat perbedaan pengaruh model konseling Kognitif Sosial teknik restrukturisasi kognitif dengan teknik Modeling terhadap peningkatan selfabasement siswa SMK Negeri 1 Singaraja.

4. terdapat perbedaan pengaruh teknik restrukturisasi kognitif dengan teknik Modeling model konseling Kognitif Sosial terhadap Self abasement siswa SMK Negeri 1 Singaraja. 


\section{Referensi}

Ainslie, G. (1975). Specious reward: A behavioral theory of impulsiveness and impulse control. Psychological Bulletin, 82(4), 463-496. https://doi.org/10.1037/h0076860

Astuti, W. M., Sumarwati, M., \& Seyiono, T. (2010). Pengaruh Terapi Kognitif Restrukturisasi Terhadap Penurunan Skor Depresi Pada Pasien Gangguan Jiwa. The Soedirman Journal of Nursing, 5(3), 164173. Retrieved from http://jks.fikes.unsoed.ac.id/index.php/jks/article/download/310/158

Azzi, R. G., Baqueira, A. P., \& Tourinho, A. C. G. D. S. (2016). Ensino na perspectiva da Teoria Social Cognitiva: discussões iniciais a partir do ensino de música. Revista Da Abem, 24, 105-115. Retrieved from http://www.abemeducacaomusical.com.br/revistas/revistaabem/index.php/revistaabem/article/vi ewFile/604/467

Ayu Sopya Yanti, Putu. (2012). Penerapan Model Konseling Behavioral Teknik Modeling Untuk Mengembangkan Sikap Empati Siswa. Singaraja (skripsi tidak diterbitkan)

Badri Sutrisno. (2012). Metode Statistik untuk Penelitian Kuantitatif. Yogyakarta: Ombak (Anggota IKAPI).

Bandura, A. (1991). Social Kognitive Theory of Self Regulation. Organization Behavior and Human Decision Processes, 50, 248-287. Retrieved from http://www.uky.edu/ eushe2/BanduraPubs/Bandura1991OBHDP.pdf

Bere, C. (2011). Psihologie Revist ă ş tiin ţ i fi co - practic ă CUPRINS The Psychology The scienti fi cal practical magazine CONTENTS. Psihologie, 1. Retrieved from http://www.psihologie.key.md/wpcontent/uploads/2011/09/Revista-Psihologie1-2011.pdf\#page $=62$

Bungin, Burhan. (2011). Metodelogi Penelitian Kuantitatif, komunikasi, ekonomi dan kebijakan public serta ilmuilmu sosial lainnya. Jakarta: Kencana Perdana Media Group

Bryant, R. A., Moulds, M. L., Guthrie, R. M., Dang, S. T., Nixon, R. D. V, Bryant, R. A., ... Suzanne, T. (2003). Imaginal Exposure Alone and Imaginal Exposure With Cognitive Restructuring in Treatment of Posttraumatic Stress Disorder. Journal of Consulting and Clinical Psychology, 71(4), 706-712. https://doi.org/10.1037/0022-006X.71.4.706

Ć, J. K. E. Š. I., \& Duyvendak, J. A. N. W. (2016). Nation and as Anti-nationalist nationalism : the paradox of Dutch national identity. Journal of the Association for The Study of Ethnicity and Nationalism, 1-17. https://doi.org/10.1111/nana.12187

Caldas, C. (2015). Anotações sobre cristologia no pensamento de Bonhoeffer, 1, 22-31. Retrieved from http://fbnovas.edu.br/revistas/index.php/pax/article/viewFile/9/74

Corey, Gerald. 2013. Teori dan Praktek Konseling \& Psikoterapi. Bandung: PT. Refika Aditama

Dantes, Nyoman. 2012. Metode Penelitian. Yogyakarta: CV Andi Offset

Devi, B., Das, M., Das, M., \& Khandelwal, B. (2017). Application of Bandura's social cognitive theory in the technology enhanced, blended learning environment. International Journal of Applied Research, 3(1), 721-724.

Dharsana, Ketut. 2013. Modul Teori-Teori Konseling. Singaraja: Jurusan Bimbingan Konseling, FIP UNDIKSHA

Dharsana, Ketut. 2013. Pengembangan Pribadi Konselor. Singaraja: Jurusan Bimbingan Konseling, FIP UNDIKSHA 
Dharsana, Ketut. 2014. Model-Model Teori, Teknik, Skill Bimbingan Konseling untuk Penulisan RPBK, Proposal, Sripsi, Tesis. Singaraja: BK FIP UNDIKSHA

Dharsana, Ketut. 2015. RPBK Seri Bimbingan Klasikal, Bimbingan Kelompok, Konseling Kelompok, Konseling Individual untuk Pengembangan Minta-2. Singaraja: BK FIP UNDIKSHA

Espejo, E. P., Gorlick, A., \& Castriotta, N. (2016). Changes in Threat-Related Cognitions and Experiential Avoidance in Group-Based Transdiagnostic CBT For Anxiety Disorders. Journal of Anxiety Disorders, 6-12. https://doi.org/10.1016/j.janxdis.2016.06.006

Faasse, K., Perera, A., Loveys, K., Grey, A., \& Petrie, K. J. (2017). Enhancing treatment effectiveness through social modelling: A pilot study. Psychology and Health, 32(5), 626-637. https://doi.org/10.1080/08870446.2017.1293056

Firdaus, M. Aziz. 2012. Metode Penelitian. Tanggerang Selatan: Jelajah Nusa

Foa, E. B., Hembree, E. A., Cahill, S. P., Rauch, S. A. M., Riggs, D. S., Feeny, N. C., ... Long, M. (2005). Randomized Trial of Prolonged Exposure for Posttraumatic Stress Disorder With and Without Cognitive Restructuring : Outcome at Academic and Community Clinics. Journal of Consulting Clinical Psychology, 73(5), 953-964. https://doi.org/10.1037/0022-006X.73.5.953

Freud, S., Mahler, G., Strauss, R., \& Sch, A. (2017). 코른골트 ( E . W . Korngold ) 오페라 《죽음의 도시 》(Die tote Stadt ) 에 나타난 20세기 초 비엔나의 음악과 사회 *, 38, 109-147. Retrieved from http://mrc.hanyang.ac.kr/wp-content/jspm/38/jspm_2017_38_04.pdf

Garriott, P. O., Raque-bogdan, T. L., Zoma, L., Mackie-hernandez, D., \& Lavin, K. (2016). Social Cognitive Predictors of Mexican American High School Students ' Math / Science Career Goals. Journal of Career Development, 1-14. https://doi.org/10.1177/0894845316633860

Gunawan, Muhammad Ali. 2013. Statistik untuk Penelitian Pendidikan. Yogyakarta: Parama Publising

Guido, D., Vendruscolo, S., Guilherme, A., Chaves, S., Medeiros, R. A., Scandiane, R., ... Leite, H. G. (2017). Estimativa da altura de árvores de. Pesquisas Agrárias E Ambientais, 5, 52-58. Retrieved from http://www.periodicoscientificos.ufmt.br/ojs/index.php/nativa/article/download/3738/pdf

Hawley, L. L., Padesky, C. A., Hollon, S. D., Mancuso, E., Laposa, J. M., Brozina, K., \& Segal, Z. V. (2017). Cognitive-Behavioral Therapy for Depression Using Mind Over Mood: CBT Skill Use and Differential Symptom Alleviation. Behavior Therapy, 48(1), 29-44. https://doi.org/10.1016/j.beth.2016.09.003

Hill, C. A. (1987). Affiliation motivation: People who need people... but in different ways. Journal of Personality and Social Psychology, 52(5), 1008-1018. https://doi.org/10.1037/0022-3514.52.5.1008

Jiansheng, Y. (2017). Art Regression : On Unconsciousness Trend of The Picture of Dorian Gray. Canadian Social Science, 13(5), 50-53. https://doi.org/10.3968/9585

Lent, R. W., Brown, S. D., \& Hackett, G. (2000). Contextual Supports and Barriers to Career Choice : A Social Cognitive Analysis. Journal of Counceling Psycology, 47(1), 36-49. Retrieved from http://www.nsfengineerstudy.org/webdocs/scct.pdf

Miniati, F. (2008). Emozioni : la vergogna, 56, 87-99. Retrieved from http://www.fupress.net/index.php/sf/article/viewFile/2901/2584

Mischel, W. (1973). TOWARD A COGNITIVE SOCIAL LEARNING. Psycology Review, 80(4), $252-283$. Retrieved from http://psych.colorado.edu/ carey/Courses/PSYC5112/Readings/psnSituation_Mische101.pdf 
Moisen, G. G., \& Frescino, T. S. (2002). Comparing fi v e modelling techniques for predicting forest characteristics. Ecological Modelling, 157, 209-225. Retrieved from ftp://131.252.97.79/Transfer/Treg/WFRE_Articles/Moisen_02_Compare5ModelMethods_ForestS tructure.pdf

Nadelhoffer, T., Wright, J. C., Echols, M., Perini, T., \& Venezia, K. (2016). Some Varieties of Humility Worth Wanting. Journal Of Moral Philosophy, 1-32. https://doi.org/10.1163/17455243-46810056

Neimeyer, R. A., Kazantzis, N., Kassler, D. M., Baker, K. D., \& Fletcher, R. (2008). Group cognitive behavioural therapy for depression outcomes predicted by willingness to engage in homework, compliance with homework, and cognitive restructuring skill acquisition. Cognitive Behaviour Therapy, 37(4), 199-215. https://doi.org/10.1080/16506070801981240

Rapee, R. M., \& Heimberg, R. G. (1997). A Cognitive-Behavioral Model of Anxiety in Social Phobia. Pergamon, 35(8), 741-743. Retrieved from https://pdfs.semanticscholar.org/b340/9ea9e4d68c1f37d408ceb27be3656d43c57e.pdf

Reksoatmodjo, Tedjo N. 2009. Statistika untuk Psikologi dan Pendidikan. Bandung: PT Refika Aditama

Ricardo, J., Paiva, B. De, Lemes, M. T., Hugo, V., Lopes, L., \& Vieira, J. A. (2016). Utilização da. Revista de Sistemas E Computação, 6(2), 103-110. Retrieved from http://revistas.unifacs.br/index.php/rsc/article/download/4432/3066

Sanisca Nanda, Ida Ayu.2012. Pegaruh Implementasi Konseling Eksistensial Humanistik dengan Teknk Modeling untuk Meningkatkan Self Esteem Siswa Teralienasi. Singaraja (skripsi tidak diterbitkan)

Staay, F. J. Van Der. (2006). Animal Models of Behavioral Dysfunctions : Basic Concepts and Classifications, and an Evaluation Strategy. Science Direct, 52, 131-159. https://doi.org/10.1016/j.brainresrev.2006.01.006

Setyosari, Punaji. 2012. Metode Penelitian Pendidikan dan Pengembangan. Jakarta: Kencana Prenada Media Group

Sudaryono, dkk. 2013. Pengembangan Instrumen Penelitian Pendidikan. Yogyakarta: Graha Ilmu

Taylor, P. J., Russ-eft, D. F., \& Chan, D. W. L. (2005). A Meta-Analytic Review of Behavior Modeling Training. Journal of Applied Psychology, 90(4), 692-709. https://doi.org/10.1037/0021-9010.90.4.692

Umar, Husein. 2004. Metode Penelitian untuk Skripsi dan Tesis Bisnis. Jakarta: PT Raja Grafindo Persada.

江光荣段文婷. (2008). 计划行为理论述评 段文婷. Advances in Psychological Science, 2, 315-320. Retrieved from

http://journal.psych.ac.cn/xlkxjz/CN/article/downloadArticleFile.do?attachType=PDF\&id=2402

\section{Conflict of Interest Disclosures:}

The authors declare that they have no significant competing financial, professional or personal interests that might have influenced the performance or presentation of the work described in this manuscript.

Copyrights Holder: Ni Putu Nia Diastuti, Dewi Arum WMP, I Ketut Dharsana 2017

https://doi.org/10.23887/128212017

Open Access Article | CC-BY Creative Commons Attribution 4.0 International License.

Word Count:
First Publication Right: BISMA The Journal of Counseling

@creative 